Research Paper: Neuroscience

\title{
Nitrobenzylthioinosine mimics adenosine to attenuate the epileptiform discharge of hippocampal neurons from epileptic rats
}

\author{
Hao Huang ${ }^{1, *}$, Jing Wang ${ }^{2, *}$, Jun Zhang ${ }^{1}$, Zhong Luo ${ }^{1}$, Dongxu Li $^{1}$, Xiaowei Qiu ${ }^{1}$, \\ Yan Peng ${ }^{1}$, Zhongxiang $X \mathbf{u}^{1}$, Ping $X \mathbf{u}^{1}$ and Zucai $X \mathbf{u}^{1}$ \\ ${ }^{1}$ Department of Neurology, Affiliated Hospital of Zunyi Medical College, Zunyi, Guizhou, China \\ 2 Department of Prevention and Health Care, Affiliated Hospital of Zunyi Medical College, Zunyi, Guizhou, China \\ * These authors have equal contribution to this work \\ Correspondence to: Ping Xu, email: xupingsci@126.com
}

Zucai Xu, email: docxzc@126.com

Keywords: epilepsy, nitrobenzylthioinosine, adenosine, adenosine A 1 receptor, Neuroscience

Received: January 06, $2017 \quad$ Accepted: March 02, $2017 \quad$ Published: March 08, 2017

Copyright: Huang et al. This is an open-access article distributed under the terms of the Creative Commons Attribution License (CC-BY), which permits unrestricted use, distribution, and reproduction in any medium, provided the original author and source are credited.

\section{ABSTRACT}

Nitrobenzylthioinosine (NBTI), a specific inhibitor of type 1 equilibrative nucleoside transporter, could regulate the extracellular adenosine concentration and have protective roles in seizures. However, the protection mechanism of NBTI in seizures remains poorly understood. Here, the expression pattern and subcellular distribution of adenosine A1 receptor were detected by Western blot analysis and double-labeling immunofluorescence staining in Lithium Chloride-Pilocarpine induced epileptic rat model. At $\mathbf{2 4} \mathrm{h}$ after pilocarpine induced rat seizures, hippocampal slices were prepared and the evoked excitatory postsynaptic currents (eEPSCs) amplitude of pyramidal neurons in hippocampus CA1 region was recorded using whole-cell patch clamp. In vivo, compared to control group, Western blotting analysis showed that the expression of adenosine A1 receptor protein was increased at $24 \mathrm{~h}$ and 72 $h$ after seizure, didn't change at 0 min and $1 \mathrm{w}$, and decreased at $2 \mathrm{w}$. Double-label immunofluorescence revealed that adenosine A1 receptor was mainly expressed in the membrane and cytoplasm of neurons. In Vitro, adenosine decreased the eEPSCs amplitude of pyramidal neurons in hippocampus CA1 region, NBTI also had the same effect. Meantime, NBTI could further inhibit eEPSCs amplitude on the basis of lower concentration adenosine $(50 \mu \mathrm{M})$, and adenosine A1 receptor inhibitor DPCPX partially reversed this effect. Taken together, we confirmed that the expression of adenosine A1 receptor protein was increased in the early seizures and decreased in the late seizures. At the same time, NBTI mimics adenosine to attenuate the epileptiform discharge through adenosine A1 receptor, which might provide a novel therapeutic approach toward the control of epilepsy.

\section{INTRODUCTION}

Epilepsy is a chronic brain disorder which characterized by recurrent unprovoked seizures and affects tens of millions of people in the world [1,2]. High seizure frequency and various kinds of burdens are the main factors influencing the quality of life in epileptic patients $[3,4]$. Increased seizure frequency is exactly associated with worse outcomes and the burdens of epilepsy. Of course, new antiepileptic drugs (AEDs) may reduce these adverse events and can improve the prognosis of patients with epilepsy [5]. However, the existing AEDs fail to prevent or cure the $20-30 \%$ of epileptic patients $[6,7]$.

Adenosine, an endogenous inhibitor of neuronal discharges [8], is released extensively during seizures, which could inhibit hippocampal glutamatergic synaptic transmission through interacting with pre- or postsynaptic adenosine A1 receptors [9-11]. At the same 
time, adenosine, as an endogenous anticonvulsant, could influence the stability of $\gamma$-aminobutyric acid type A receptor through the interaction with adenosine receptors [12]. Previous studies have shown that modulation and activation of adenosine A1 receptor could influence the frequency of spontaneous recurrent seizures and hippocampal excitability of chronic pilocarpine epileptic rats, and also have an anticonvulsant effect on seizures elicited from piriform cortex kindling by electrical stimulation $[13,14]$.

Type 1 equilibrative nucleoside transporter (ENT1) is one kind of most abundant and widely distributed in plasma membrane nucleoside transporter in mammalian cells and tissues $[15,16]$, and ENT1 is regarded as a critical transporter for the regulation of adenosine, and for the cellular uptake of chemotherapeutic nucleoside analogs [17, 18]. Previous study has illustrated that ectogenic adenosine A1 agonists that are transported by ENT1 could be applied to target central nervous system (CNS) disorders because of its widely distributed in the brain [19]. In addition, nitrobenzylthioinosine (NBTI) [20], a specific inhibitor of ENT1, could retard the adenosine disappearance from extracellular cleft through blocking adenosine uptake into cells, and has protective effects during seizures [21-23]. What is more, pretreated with NBTI could prolong the latency to reach the seizure status of animals $[22,23]$.

Based on the physiological roles of adenosine A1 receptor and NBTI in the CNS, we hypothesized that inhibition of glutamergic neurotransmission by adenosine via its A1 receptor may be mimicked by NBTI to attenuate the epileptiform discharge of hippocampal neurons from epileptic rats. This study was designed to determine the expression pattern and cellular distribution of adenosine A1 receptor in lithium chloride-pilocarpine induced epileptic rats using Western blot analysis and double-labeling immunofluorescence staining, and to evaluate the role of NBTI on the epileptiform discharge of hippocampus neurons from epileptic rats using the wholecell patch clamp technique.

\section{RESULTS}

\section{The expression of adenosine $\mathrm{A} 1$ receptor in the hippocampus of epileptic rats}

To test whether adenosine A1 receptor was altered in rat seizure model, we measured dynamic changes of adenosine A1 receptor in the hippocampus of pilocarpine induced seizure rats. As shown in Figure 1A and 1B (n $=5$ ), the adenosine A1 receptor expression, compared to control group $(0.14 \pm 0.02)$, was peaked at $24 \mathrm{~h}(0.50 \pm 0.06)$ after seizure and remained significantly higher at 72 h $(0.24 \pm 0.02, P<0.05)$. However, the expression of adenosine A1 receptor at $0 \mathrm{~min}(0.15 \pm 0.02)$ and $1 \mathrm{~W}$ $(0.13 \pm 0.01)$ had no significant difference compared with control group $(P>0.05)$. In addition, at $2 \mathrm{w}(0.07 \pm 0.01)$

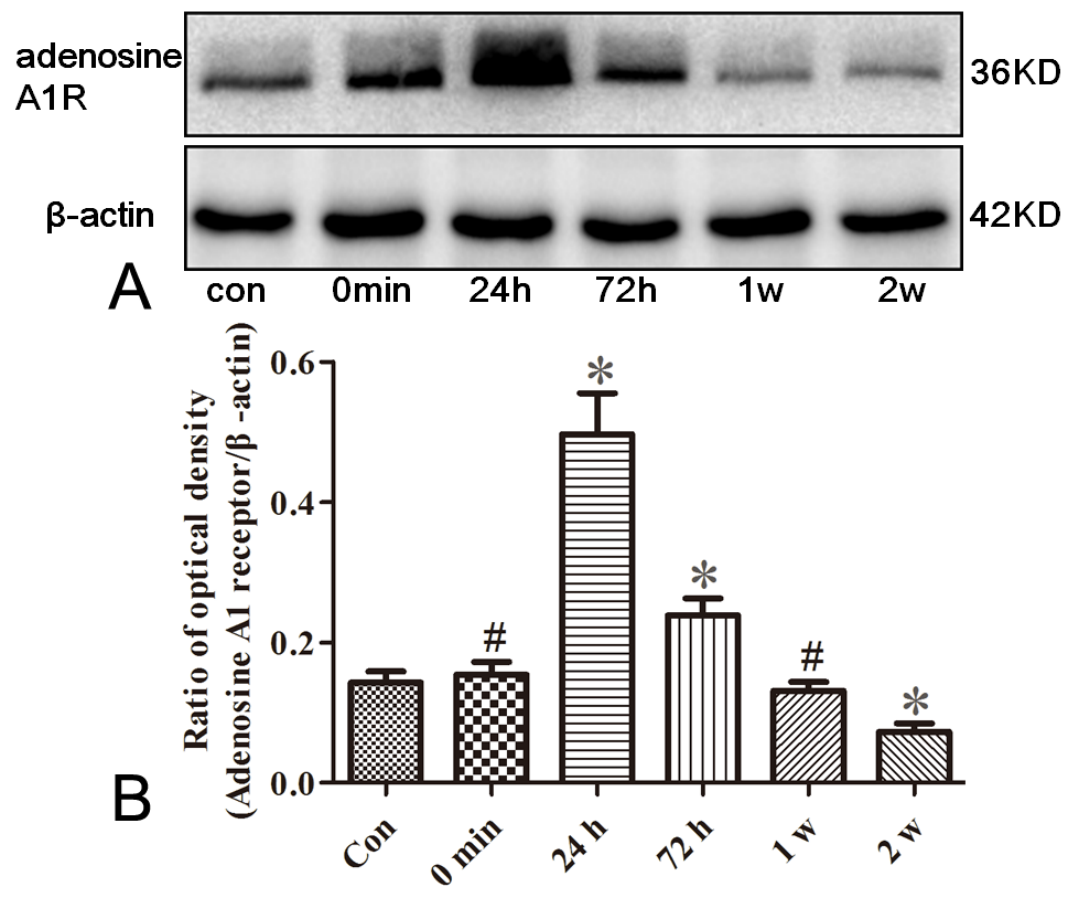

Figure 1: Western blotting analysis for adenosine A1 receptor in the hippocampus of rats. The immunoreactive staining of adenosine A1 receptor in epileptic seizure rats are stronger than those in controls (Con) at 24 and $72 \mathrm{~h}$ after seizures, which are the same expression tendency as in controls at $0 \mathrm{~min}$ and $1 \mathrm{w}$ time point. At $2 \mathrm{w}$ after the onset of seizures, the adenosine A1 receptor expression is weaker than that in controls $\left(* P<0.01,{ }^{*} P>0.05, n=5\right)$. 
after seizures, the adenosine A1 receptor expression is weaker than that in controls $(P<0.05)$.

\section{Localization of adenosine $\mathrm{A} 1$ receptor in epileptic rats}

To determine the cellular distribution of adenosine A1 receptor, double-labeling immunofluorescence staining experiments were performed on the hippocampus of epileptic rats. At $24 \mathrm{~h}$ after seizures, we observed abundant immunoreactivity adenosine A1 receptor positive cells expressed in CA3 area of hippocampus (Figure 2A and 2D). Moreover, adenosine A1 receptor was colocalized with the neuron dendritic marker microtubule-associated protein 2 (MAP2) in the CA3 area of hippocampus (Figure $2 \mathrm{C}, 2 \mathrm{~F})$.

\section{NBTI mimics adenosine to inhibit eEPSCs mediated by adenosine $\mathrm{A} 1$ receptor}

To test whether NBTI mimics adenosine effecting on eEPSCs mediated by adenosine A1 receptor, we investigated the role of adenosine and adenosine A1 receptor antagonist DPCPX in the process of NBTI regulating eEPSCs. At $24 \mathrm{~h}$ after pilocarpine induced rat seizures, preparation of hippocampal slices, selecting the pyramidal neurons of hippocampus CA1 region, the eEPSCs amplitudes were recorded by the whole-cell patch clamp, and they were stable during the whole recording process, which was consistent with previous study [24]. Compared to the eEPSCs amplitude of control epilepsy group $(1.44 \pm 0.05)$, bath application of NBTI (100 nM) significantly reduced eEPSCs amplitude at $10 \mathrm{~min}$ $(0.67 \pm 0.06)$ and $30 \mathrm{~min}(0.63 \pm 0.08)$, while application of A1 receptor inhibitor DPCPX $(10 \mu \mathrm{M})$ partially reversed this effect $(0.87 \pm 0.08$, Figure $3 \mathrm{~A}$ and $3 \mathrm{~B}, n=5)$. In addition, inhibition of eEPSCs amplitude by adenosine was mimicked by NBTI (100 nM), and the reduced eEPSCs amplitude by adenosine (50M, 0.45 \pm 0.06$)$ were further inhibited by NBTI ( $100 \mathrm{nM}, 0.17 \pm 0.04$, Figure 4A and $4 \mathrm{~B}, n=5)$. However, when adenosine concentration was saturated $(100 \mu \mathrm{M}, 0.15 \pm 0.02)$, no further inhibitory effect of NBTI on eEPSC amplitude was observed $(0.15 \pm 0.02$, Figure $5 \mathrm{~A}$ and $5 \mathrm{~B}, n=5)$, so the inhibition of eEPSCs amplitude by adenosine was dose dependent. These results indicate that the effect of NBTI on eEPSCs was mediated by adenosine $\mathrm{A} 1$ receptor.

\section{DISCUSSION}

In this study, we first measured adenosine A1 receptor expression in control and epileptic seizure rats.

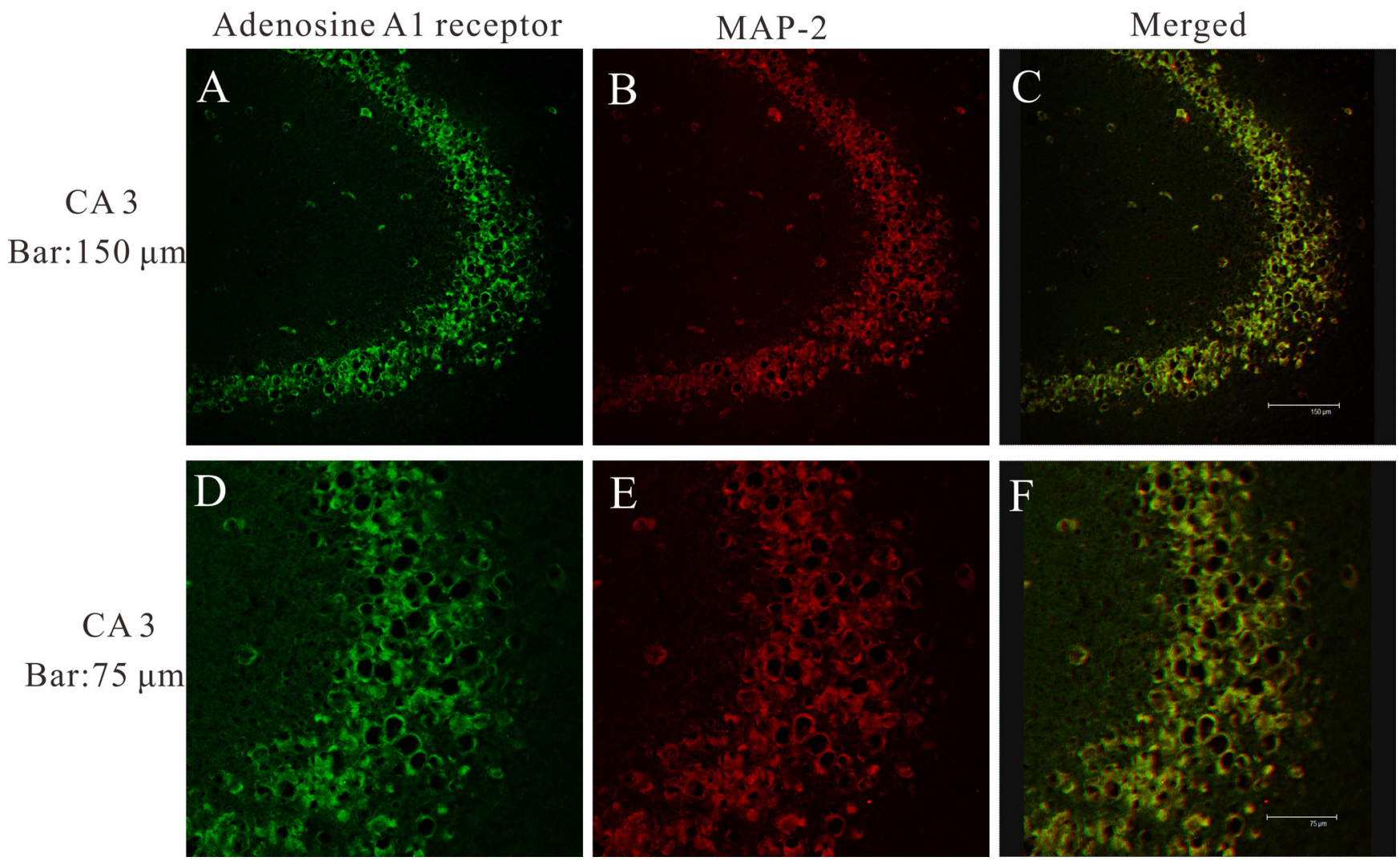

Figure 2: A laser scanning confocal image of adenosine A1 receptor in epileptic rat 24 h after seizures. Adenosine A1 receptor (green) and MAP2 (red) are co-expressed within neurons in the CA3 area of hippocampus. 

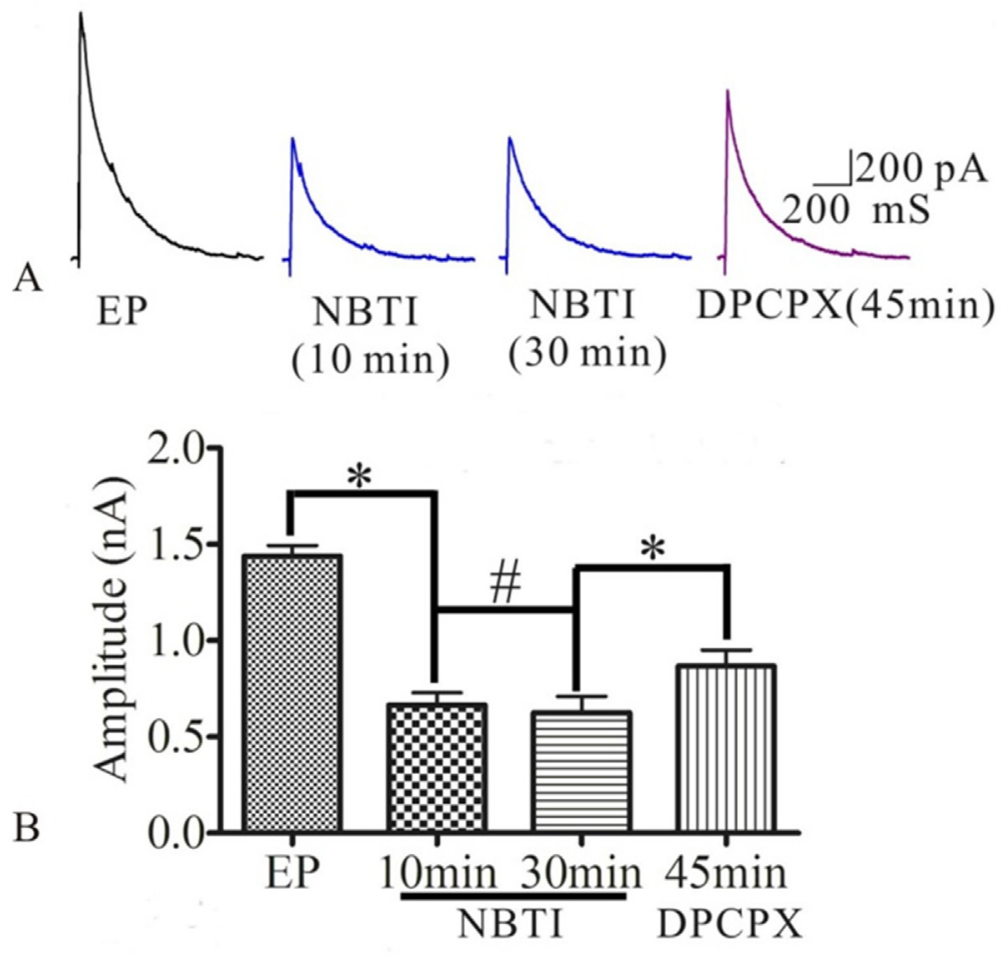

Figure 3: A. Respective eEPSCs in the presence or absence of NBTI (100 nM) or adenosine A1 receptor antagonist DPCPX (10 $\mu \mathrm{M}) .10$, 30 and 45 min denote times after recording. B. Bar plot summary of eEPSC amplitude from A $\left(* P<0.01,{ }^{*} P>0.05, n=5\right)$.

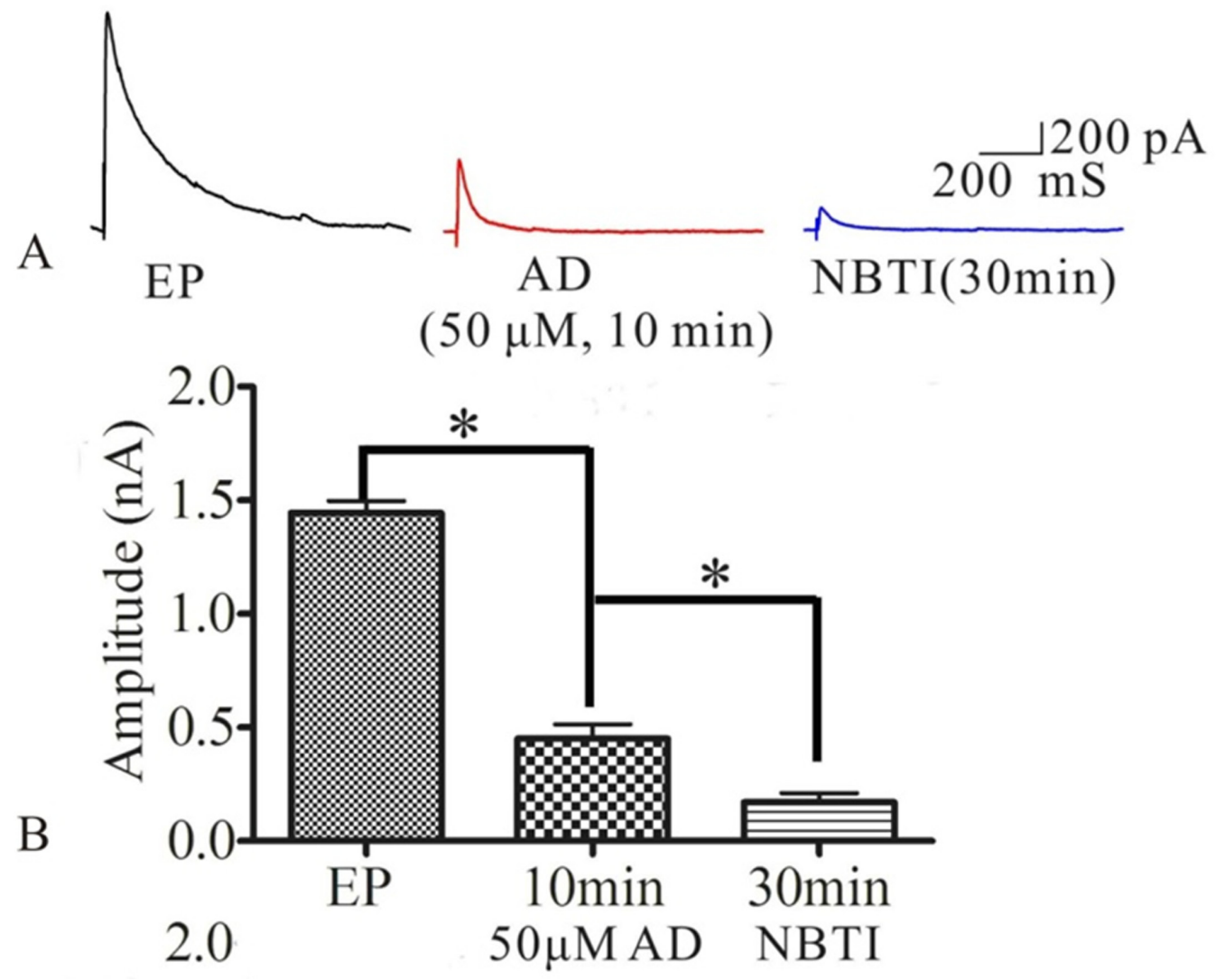

Figure 4: A. Respective eEPSCs in the presence or absence of AD $(50 \mu \mathrm{M})$ or NBTI $(100 \mathrm{nM}) .10$ min and 30min denote times after recording. B. Bar plot summary of eEPSC amplitude from $\mathrm{A}(* P<0.01, n=5)$. 
Then, we tested whether NBTI could mimic adenosine to attenuate the epileptiform discharge of epileptic hippocampus neurons. Interestingly, we observed that adenosine A1 receptor was mainly expressed in the membrane and cytoplasm of neurons, and the expression of adenosine A1 receptor protein was fluctuated, which increased at $24 \mathrm{~h}$ and $72 \mathrm{~h}$ after seizure, didn't change at $0 \mathrm{~min}$ and $1 \mathrm{w}$, and decreased at $2 \mathrm{w}$. At the same time, we observed that NBTI could mimic adenosine reducing eEPSCs amplitude through adenosine A1 receptor.

Adenosine, a well-known endogenous anticonvulsant modulate molecular, could regulate synaptic transmission and synaptic activity through interacting with adenosine A1 receptor [25, 26], while adenosine A1 receptor is closely related to neural network excitability $[27,28]$, and could reduce glutamatergic neurotransmitter release through inhibiting voltage-gated channels calcium ion influx [29], inhibit neuronal activity [25] and mediate seizure arrest [27, 30, 31]. So, based on the physiological roles of adenosine A1 receptor in the brain, adenosine A1 receptor may be associated with the pathogenesis of epilepsy.

In present study, we found that adenosine A1 receptor was mainly expressed in the membrane and cytoplasm of neurons, and the expression of adenosine A1 receptor protein was increased in the early seizures
( $24 \mathrm{~h}$ and $72 \mathrm{~h}$ after seizure), and decreased in the late seizures ( $2 \mathrm{w}$ after seizure). We speculate that increased adenosine A1 receptor protein in the early seizures may be related to the start of endogenous antiepileptic mechanism. Previous studies have shown that neural over activity in the early seizures induced the release of adenosine, which is an endogenous inhibitory neuromodulator and could mediates seizure arrest and limit the intensity or duration of seizures through interacting with adenosine A1 receptor [31-33]. While decreased adenosine A1 receptor protein expression in the late seizures may involve in epileptogenesis and recurrent seizures, which could consume endogenous antiepileptic substance. A growing number of studies have shown that adenosine A1 receptor has antiepileptic effects, adenosine A1 receptor agonists limits convulsions and seizures of experimental epileptic animals [34-37], while the antagonists of adenosine A1 receptor could worsen seizures [38]. Besides, spontaneous electrographic seizures were observed in the cerebral cortex of inactivated adenosine A1 receptor experimental epileptic mice [28], and in experimental traumatic brain injury (TBI) animal model, adenosine A1 receptor knockout promoted status epilepticus after TBI [39]. Moreover, modulation and activation of adenosine A1 receptors could influence the frequency of spontaneous recurrent seizures and hippocampal excitability of chronic
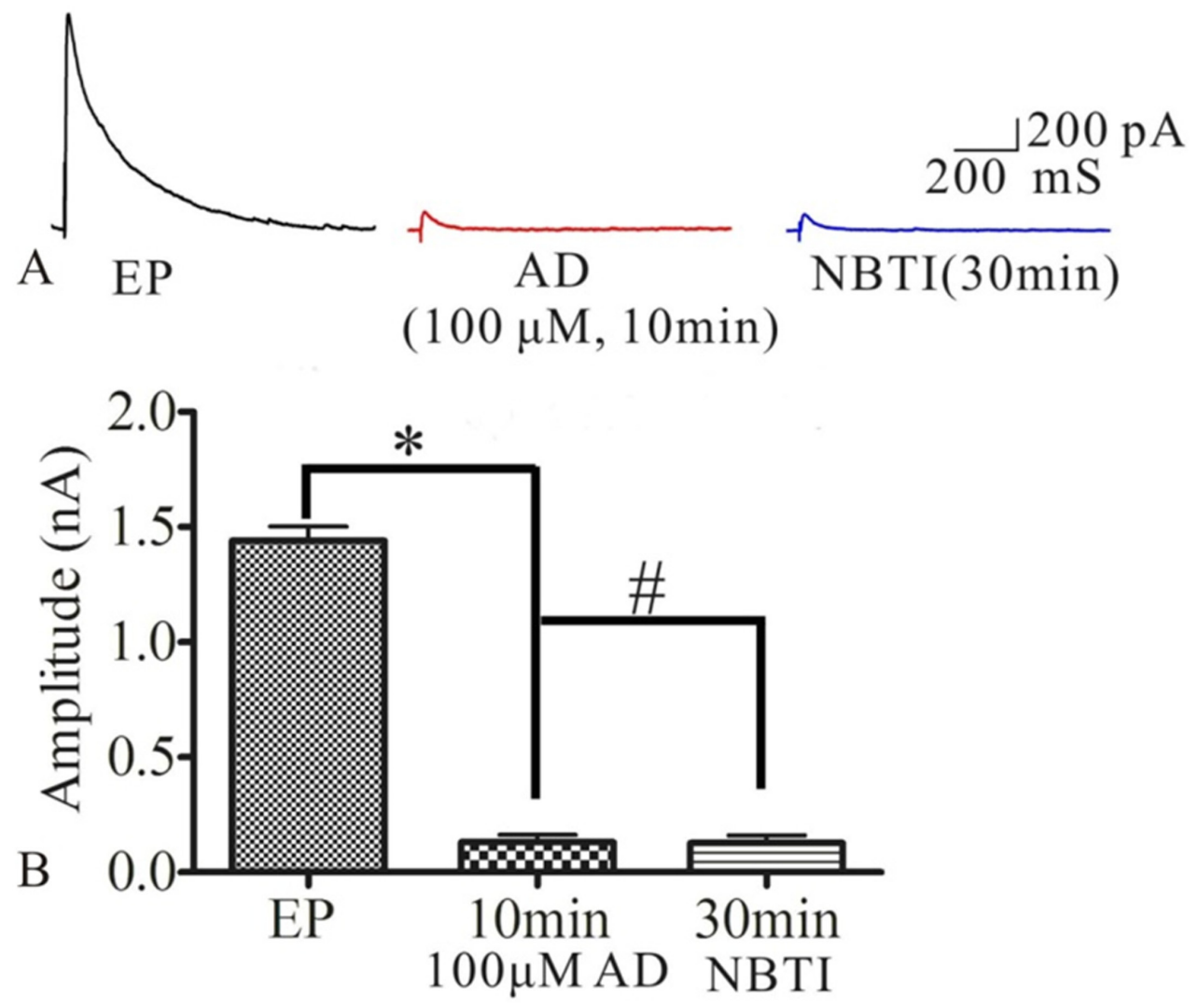

Figure 5: A. Respective eEPSCs in the presence or absence of AD $(100 \mu \mathrm{M})$ or NBTI $(100 \mathrm{nM}) .10$ min and 30min denote times after recording. B. Bar plot summary of eEPSC amplitude from $\mathrm{A}\left({ }^{*} P<0.01, \# P>0.05, n=5\right)$. 
pilocarpine-induced epileptic rats, and also have an anticonvulsant effect on seizures elicited from piriform cortex kindling by electrical stimulation [13, 14].

It is well-known that adenosine could inhibit the excitability of neurons through regulating synaptic transmission, synaptic activity and suppressing synchronous discharges $[8,25,26,40]$. ENT1, one subtype of equilibrative nucleoside transporter, is regarded as a critical transporter for the regulation of adenosine and glutamatergic neurotransmission [18]. Under the condition of ischemia and hypoxia, ENT1 was over expressed and could reduce extracellular adenosine levels in mouse neurons [41], while ENT1 inhibitor (NBTI) could prolong onset latency for the development of seizures and status epilepticus in the epileptic animal models through increasing extracellular adenosine levels [21-23], and reduce evoked EPSC in lamina II neurons of rat spinal dorsal horn [24], suggesting that NBTI could reduce the excitability of neurons though adenosine signaling. Building on the earlier research, we have found that ENT1 played an important role in the epileptogenesis, and its specific inhibitor NBTI could attenuate seizure severity and prolong onset latency in pilocarpine-induced seizure rats [42]. In this study, we observed that adenosine decreased the eEPSCs amplitude of pyramidal neurons in hippocampus $\mathrm{CA} 1$ region at $24 \mathrm{~h}$ after pilocarpine-induced rat seizures, NBTI also had the same effect. Meantime, NBTI could further inhibit eEPSCs amplitude on the basis of lower concentration adenosine $(50 \mu \mathrm{M})$, and adenosine A1 receptor inhibitor DPCPX partially reversed this effect. So we thought that NBTI could mimic adenosine reducing eEPSCs amplitude through adenosine A1 receptor.

In conclusion, the abnormal expression of adenosine A1 receptor in the hippocampus of epileptic rats might be involved in the pathogenesis of epilepsy, NBTI mimics adenosine reducing epileptiform discharge through adenosine A1 receptor might provide a novel therapeutic approach toward the control of epilepsy.

\section{MATERIALS AND METHODS}

\section{Epileptic model of rats}

All experimental procedures were approved by the Commission of Zunyi Medical College for the Ethics of Experiments on Animals in accordance with China Animal Welfare Legislation standards. The adult male Sprague-Dawley (SD) rats weighing about $200 \mathrm{~g}$ were obtained from the Experimental Animal Center of Zunyi Medical College, China. The rats were maintained in a temperature controlled room $\left(22-24{ }^{\circ} \mathrm{C}\right)$ with a $12 \mathrm{~h}$ light and $12 \mathrm{~h}$ dark cycle as well as free access to food and water. The rat model of epilepsy was produced as before [42]. Briefly, male rats were intraperitoneal (i.p.) injected lithium chloride $(127 \mathrm{mg} / \mathrm{kg}$, Sigma-Aldrich Co., St. Louis, MO, USA) $20 \mathrm{~h}$ prior to the administration of pilocarpine (i.p. $50 \mathrm{mg} / \mathrm{kg}$, Sigma-Aldrich). Furthermore, the rats were pretreated with atropine methyl nitrate $(1 \mathrm{mg} /$ $\mathrm{kg}) 30 \mathrm{~min}$ prior to pilocarpine administration. The rats received repeated i.p. injections of $10 \mathrm{mg} / \mathrm{kg}$ pilocarpine every 30 min until they developed epileptic seizures. The epileptic seizures were evaluated by Racine score [43]. Only convulsive seizures reached to the stage 4 or 5 were considered as being successfully kindled [44]. All rats were continuously monitored by a video recording system after injection of pilocarpine until they were sacrificed. The normal rats in control group were administration of an equal volume of saline instead of pilocarpine. The seizure rats were sacrifced at $0 \mathrm{~min}, 1,3,7$ and 14 days after seizures, while the control group of rats were sacrifced at day 1 , and the brain tissues were removed immediately for analysis (each group $n=5$ ).

\section{Western blotting}

Western blotting was performed as previous report to detect the expression of adenosine A1 receptor in normal and epileptic rats [45]. The rats' hippocampal tissues were stored in liquid nitrogen for western blotting analysis. According to the manufacturers' instructions, protein was extracted, and the protein concentration was measured by the Enhanced BCA Protein Assay Kit (Beyotime Institute of Biotechnology, Shanghai, China). A total of $50 \mu \mathrm{g}$ protein was separated by $10 \%$ SDS-PAGE and then transferred to polyvinylidene fluoride membranes (Millipore Corp, Massachusetts, USA, $250 \mathrm{~mA}, 60 \mathrm{~min}$ ). The primary antibodies were used as follows: rabbit antiadenosine A1 receptor (1:500, Santa Cruz Biotechnology, $\mathrm{CA})$ and rabbit anti- $\beta$-actin (1:1000, Beijing $4 \mathrm{~A}$ Biotech Co., Ltd, Beijing, China). The membranes were washed 4 $\times 10$ min with Tween-20/Tris-buffered saline and incubated with the appropriate diluted horseradish peroxidase-tagged secondary antibody (1:3,000, Santa Cruz Biotechnology, CA). The immunoreactive protein bands were visualized using an enhanced chemiluminescence substrate kit (Beyotime) before digital scanning (Bio-Rad Laboratories, California, USA). Blots intensities were calculated with the Quantity One software (Bio-Rad Laboratories, Hercules, CA, USA).

\section{Immunofluorescence}

To detect the location of adenosine A1 receptor in hippocampus of epileptic rats, immunoreactivity of adenosine A1 receptor was observed by immunofluorescence. Brain hippocampus tissues was fixed in $4 \%$ paraformaldehyde overnight at $4{ }^{\circ} \mathrm{C}$, then were respectively put in $20 \%$ and $30 \%$ graded sucrose solution for $48 \mathrm{~h}$. Followed, 10- $\mu \mathrm{m}$-thick frozen sections 
were cut on a freezing microtome and mounted on the polylysine-coated slides for immunofluorescence. The sections were dried at room temperature for $8 \mathrm{~min}$ and immersed in acetone for $15 \mathrm{~min}$. After washed with PBS three times ( 5 min per time), the slices were heated in $0.01 \mathrm{M}$ citric acid ( $\mathrm{pH}$ 6.0) for $20 \mathrm{~min}$ at $92-98{ }^{\circ} \mathrm{C}$ for antigen recovery. Then, the slices were permeabilized with $0.5 \%$ Triton X-100 and incubated in normal goat serum (Zhongshan Golden Bridge, Inc., Beijing, China) for 30 min. Slices were incubated in rabbit anti adenosine A1 receptor (1:100; Santa) and mouse anti-MAP2 antibody (1:100; Boster, Wuhan, China) overnight at $4{ }^{\circ} \mathrm{C}$. After washed with PBS three times (5 min per time), the slices were incubated with anti-rabbit-FITC (green) and antimouse-TRITC (red) (1:100, Zhongshan Golden Bridge) for $60 \mathrm{~min}$ and mounted with $50 \%$ glycerol and $50 \%$ PBS in the dark. The fluorescence was detected by a laser scanning confocal microscopy (Leica, Heidelberg) on an Olympus IX70 inverted microscope (Olympus, Tokyo, Japan).

\section{Hippocampal brain slices preparation for Whole- cell patch clamp}

According to previous report [42], the hippocampal brain slices for Whole-cell patch clamp were prepared as following. The SD rats were anesthetized by $3.5 \%$ chloral hydrate $(1 \mathrm{ml} / 100 \mathrm{~g}$, i.p.). The limbs were fixed, chest was opened and inferior vena cava was clamped. After cardiac perfusion by $0{ }^{\circ} \mathrm{C}$ slices liquid (containing in $\mathrm{mM}$ : $\mathrm{KCL}$, 2.5; $\mathrm{NaH} 2 \mathrm{PO} 4.2 \mathrm{H} 2 \mathrm{O}, 1.25 ; \mathrm{MgCl}_{2} \mathrm{H}_{2} \mathrm{O}, 6$; $\mathrm{CaCl} 2,1$; NaHCO3, 26; sucrose, 220; glucose, 10), the whole brain was removed and placed in $0{ }^{\circ} \mathrm{C}$ slice liquid for $3 \mathrm{~min}$, then chopped into $350 \mu \mathrm{m}$ thickness using an oscillating tissue slicer (Campden, NVSLM1), and were transferred to $37{ }^{\circ} \mathrm{C}$ artificial cerebrospinal fluid (ACSF, in $\mathrm{mM}$ : $\mathrm{NaCl}$, $124 ; \mathrm{KCl}, 3 ; \mathrm{NaH}_{2} \mathrm{PO}_{4} .2 \mathrm{H}_{2} \mathrm{O}, 1.23 ; \mathrm{NaHCO}_{3}, 26 ; \mathrm{CaCl}_{2}, 2$; $\mathrm{MgCl}_{2}, 2$; glucose, 10 , buffered with $95 \% \mathrm{O}_{2}-5 \% \mathrm{CO}_{2}$ ) for 1 $\mathrm{h}$, then transferred to $23{ }^{\circ} \mathrm{C} \mathrm{ACSF}$ for $30 \mathrm{~min}$.

\section{Whole-cell patch clamp recording}

The following experiments were performed at 23 ${ }^{\circ} \mathrm{C}$. For recording the excitatory postsynaptic currents (EPSCs), a patch pipette (2-4 $\Omega \mathrm{M})$ was filled with intracellular solution (mM): 130 Cs-methanesulfonate, 10 HEPES, $10 \mathrm{CsCl}, 4 \mathrm{NaCl}, 1 \mathrm{MgCl}_{2}, 1$ EGTA, $5 \mathrm{NMG}$, $5 \mathrm{MgATP}$, and $0.5 \mathrm{Na}_{2} \mathrm{GTP}$ and 12 phosphocreatine, $\mathrm{pH}$ $7.2(275-290 \mathrm{mOsm})$. Bicuculline $(10 \mu \mathrm{M})$ was added to block GABA mediated components in ACSF and record eEPSCs. In the eEPSCs recordings, a bipolar stainless steel electrode was placed in about $150 \mu \mathrm{m}$ dorsolateral region of the recorded neurons, with a $40 \mu \mathrm{S}, 60 \mu \mathrm{A}$ and $0.1 \mathrm{~Hz}$ stimulus. Membrane potential was held at +40 $\mathrm{mV}$. The signal was amplified using a Multiclamp 700B amplifier (Axon, USA) and digitized with a Digidata $1322 \mathrm{~A}$. Data were filtered at $10 \mathrm{kHz}$ and then recorded with pClamp 9.2 software (Molecular Devices, Sunnyvale, CA, USA).

\section{Statistical analysis}

All data were expressed as mean \pm standard error of mean (SEM), and the statistical analyses were performed with the SPSS 18.0, statistical comparisons were made by one-way ANOVA or Student's t test, $P<0.05$ was considered significant.

\section{Abbreviations}

AEDs, antiepileptic drugs; CNS, central nervous system; DPCPX, 3-dipropyl-8-cyclopentylxanthine; eEPSCs, evoked excitatory postsynaptic currents; ENT1, Type 1 equilibrative nucleoside transporter; i.p., intraperitoneal; NBTI, nitrobenzylthioinosine; SD, Sprague-Dawley; TBI, traumatic brain injury.

\section{Authors' contributions}

Zucai Xu made substantial contribution to conception and design and performance of the study. Hao Huang, Jing Wang, Zhong Luo and Dongxu Li participated in performance of all in vivo experiments, Xiaowei Qiu, Yan Peng and Zhongxiang Xu participated in performance of the whole-cell patch clamp experiments, Jun Zhang and Ping $\mathrm{Xu}$ carried out the data analysis. Hao Huang participated in performance of the study and in writing the manuscript. All authors read and approved the final manuscript.

\section{ACKNOWLEDGMENTS}

The author's research was supported by National Natural Science Foundation of China (No: 81660227, 81560224 and 81260201), Guizhou Provincial Science and Technology Foundation (No: [2013] 2327), Zunyi city outstanding youth science and technology talent cultivation project (No: [2014]10), Guizhou province science and technology cooperation project (No: [2015]7520) and Guizhou province health and family planning commission science and technology foundation (No: gzwjkj 2015-1-052). The authors sincerely thank the National Board of the Medical Affairs and the local ethics committee.

\section{CONFLICTS OF INTEREST}

The authors declare no conflict of interest. 


\section{FUNDING}

The author's research was supported by National Natural Science Foundation of China (No: 81660227, 81560224 and 81260201), Guizhou Provincial Science and Technology Foundation (No: [2013] 2327), Zunyi city outstanding youth science and technology talent cultivation project (No: [2014]10), Guizhou province science and technology cooperation project (No: [2015]7520) and Guizhou province health and family planning commission science and technology foundation (No: gzwjkj 2015-1-052).

\section{REFERENCES}

1. Wang W, Wang X, Chen L, Zhang Y, Xu Z, Liu J, Jiang G, Li J, Zhang X, Wang K, Wang J, Chen G, Luo J. The microRNA miR-124 suppresses seizure activity and regulates CREB1 activity. Expert Rev Mol Med. 2016; 18: e4. doi: 10.1017/erm.2016.3.

2. Liu X, Ou S, Xu T, Liu S, Yuan J, Huang H, Qin L, Yang H, Chen L, Tan X, Chen Y. New differentially expressed genes and differential DNA methylation underlying refractory epilepsy. Oncotarget. 2016; 7:87402-87416. doi: 10.18632/ oncotarget.13642.

3. Tedrus GM, Fonseca LC, Carvalho RM. Epilepsy and quality of life: socio-demographic and clinical aspects, and psychiatric co-morbidity. Arq Neuropsiquiatr. 2013; 71: 385-91. doi: 10.1590/0004-282x20130044.

4. Wagner RG, Ibinda F, Tollman S, Lindholm L, Newton CR, Bertram MY. Differing Methods and Definitions Influence DALY estimates: Using Population-Based Data to Calculate the Burden of Convulsive Epilepsy in Rural South Africa. PLoS One. 2015; 10: e0145300. doi: 10.1371/ journal.pone.0145300.

5. Gupta S, Kwan P, Faught E, Tsong W, Forsythe A, Ryvlin P. Understanding the burden of idiopathic generalized epilepsy in the United States, Europe, and Brazil: An analysis from the National Health and Wellness Survey. Epilepsy Behav. 2016; 55: 146-56. doi: 10.1016/j. yebeh.2015.12.018.

6. Simonato M, Loscher W, Cole AJ, Dudek FE, Engel J Jr, Kaminski RM, Loeb JA, Scharfman H, Staley KJ, Velisek L, Klitgaard H. Finding a better drug for epilepsy: preclinical screening strategies and experimental trial design. Epilepsia. 2012; 53: 1860-7. doi: 10.1111/j.15281167.2012.03541.x.

7. Boison D. The Biochemistry and Epigenetics of Epilepsy: Focus on Adenosine and Glycine. Front Mol Neurosci. 2016; 9: 26. doi: 10.3389/fnmol.2016.00026.

8. Dale N, Frenguelli BG. Release of adenosine and ATP during ischemia and epilepsy. Curr Neuropharmacol. 2009; 7: 160-79. doi: 10.2174/157015909789152146.

9. Kommajosyula SP, Randall ME, Faingold CL. Inhibition of adenosine metabolism induces changes in post-ictal depression, respiration, and mortality in genetically epilepsy prone rats. Epilepsy Res. 2016; 119: 13-9. doi: 10.1016/j. eplepsyres.2015.11.001.

10. Honore P, Buritova J, Chapman V, Besson JM. UP 20256 , an adenosine analogue, selectively acts via A1 receptors to significantly decrease noxiously-evoked spinal c-Fos protein expression. Pain. 1998; 75: 281-93.

11. Avsar E, Empson RM. Adenosine acting via A1 receptors, controls the transition to status epilepticus-like behaviour in an in vitro model of epilepsy. Neuropharmacology. 2004; 47: 427-37. doi: 10.1016/j.neuropharm.2004.04.015.

12. Roseti C, Martinello K, Fucile S, Piccari V, Mascia A, Di Gennaro G, Quarato PP, Manfredi M, Esposito V, Cantore G, Arcella A, Simonato M, Fredholm BB, et al. Adenosine receptor antagonists alter the stability of human epileptic GABAA receptors. Proc Natl Acad Sci U S A. 2008; 105: 15118-23. doi: 10.1073/pnas.0807277105.

13. Amorim BO, Hamani C, Ferreira E, Miranda MF, Fernandes MJ, Rodrigues AM, de Almeida AC, Covolan L. Effects of A1 receptor agonist/antagonist on spontaneous seizures in pilocarpine-induced epileptic rats. Epilepsy Behav. 2016; 61: 168-73. doi: 10.1016/j.yebeh.2016.05.036.

14. Zeraati M, Mirnajafi-Zadeh J, Fathollahi Y, Namvar $\mathrm{S}$, Rezvani ME. Adenosine A1 and A2A receptors of hippocampal CA1 region have opposite effects on piriform cortex kindled seizures in rats. Seizure. 2006; 15: 41-8. doi: 10.1016/j.seizure.2005.10.006.

15. Lee Y, Koay EJ, Zhang W, Qin L, Kirui DK, Hussain F, Shen H, Ferrari M. Human equilibrative nucleoside transporter-1 knockdown tunes cellular mechanics through epithelial-mesenchymal transition in pancreatic cancer cells. PLoS One. 2014; 9: e107973. doi: 10.1371/journal. pone. 0107973 .

16. Endres CJ, Moss AM, Ishida K, Govindarajan R, Unadkat JD. The role of the equilibrative nucleoside transporter 1 on tissue and fetal distribution of ribavirin in the mouse. Biopharm Drug Dispos. 2016; 37: 336-44. doi: 10.1002/ bdd.2015.

17. Dolezal T. Adenosine: a selfish-immunity signal? Oncotarget. 2015; 6: 32307-8. doi: 10.18632/ oncotarget.4685.

18. Hughes SJ, Cravetchi X, Vilas G, Hammond JR. Adenosine A1 receptor activation modulates human equilibrative nucleoside transporter 1 (hENT1) activity via PKCmediated phosphorylation of serine-281. Cell Signal. 2015; 27: 1008-18. doi: 10.1016/j.cellsig.2015.02.023.

19. Lepist EI, Damaraju VL, Zhang J, Gati WP, Yao SY, Smith KM, Karpinski E, Young JD, Leung KH, Cass CE. Transport of A1 adenosine receptor agonist tecadenoson by human and mouse nucleoside transporters: evidence for blood-brain barrier transport by murine equilibrative nucleoside transporter $1 \mathrm{mENT1}$. Drug Metab Dispos. 2013; 41: 916-22. doi: 10.1124/dmd.112.049858.

20. Minor TR, Rowe M, Cullen PK, Furst S. Enhancing brain 
adenosine signaling with the nucleoside transport blocker NBTI (S-(4-nitrobenzyl)-6-theoinosine) mimics the effects of inescapable shock on later shuttle-escape performance in rats. Behav Neurosci. 2008; 122: 1236-47. doi: 10.1037/ a0013143.

21. Siebel AM, Menezes FP, Capiotti KM, Kist LW, da Costa Schaefer I, Frantz JZ, Bogo MR, Da Silva RS, Bonan CD. Role of adenosine signaling on pentylenetetrazole-induced seizures in zebrafish. Zebrafish. 2015; 12: 127-36. doi: 10.1089/zeb.2014.1004.

22. George B, Kulkarni SK. Modulation of lithium-pilocarpineinduced status epilepticus by adenosinergic agents. Methods Find Exp Clin Pharmacol. 1997; 19: 329-33. doi:

23. Zhang G, Franklin PH, Murray TF. Manipulation of endogenous adenosine in the rat prepiriform cortex modulates seizure susceptibility. J Pharmacol Exp Ther. 1993; 264: 1415-24. doi:

24. Ackley MA, Governo RJ, Cass CE, Young JD, Baldwin SA, King AE. Control of glutamatergic neurotransmission in the rat spinal dorsal horn by the nucleoside transporter ENT1. J Physiol. 2003; 548: 507-17. doi: 10.1113/ jphysiol.2002.038091.

25. Dunwiddie TV, Masino SA. The role and regulation of adenosine in the central nervous system. Annu Rev Neurosci. 2001; 24: 31-55. doi: 10.1146/annurev. neuro.24.1.31.

26. Boison D, Stewart KA. Therapeutic epilepsy research: from pharmacological rationale to focal adenosine augmentation. Biochem Pharmacol. 2009; 78: 1428-37. doi: 10.1016/j. bcp.2009.08.005.

27. Li T, Steinbeck JA, Lusardi T, Koch P, Lan JQ, Wilz A, Segschneider M, Simon RP, Brustle O, Boison D. Suppression of kindling epileptogenesis by adenosine releasing stem cell-derived brain implants. Brain. 2007; 130: 1276-88. doi: 10.1093/brain/awm057.

28. Fedele DE, Li T, Lan JQ, Fredholm BB, Boison D. Adenosine A1 receptors are crucial in keeping an epileptic focus localized. Exp Neurol. 2006; 200: 184-90. doi: 10.1016/j.expneurol.2006.02.133.

29. Gundlfinger A, Bischofberger J, Johenning FW, Torvinen M, Schmitz D, Breustedt J. Adenosine modulates transmission at the hippocampal mossy fibre synapse via direct inhibition of presynaptic calcium channels. J Physiol. 2007; 582: 263-77. doi: 10.1113/jphysiol.2007.132613.

30. During MJ, Spencer DD. Adenosine: a potential mediator of seizure arrest and postictal refractoriness. Ann Neurol. 1992; 32: 618-24. doi: 10.1002/ana.410320504.

31. Ilie A, Raimondo JV, Akerman CJ. Adenosine release during seizures attenuates GABAA receptor-mediated depolarization. J Neurosci. 2012; 32: 5321-32. doi: 10.1523/ jneurosci.5412-11.2012.

32. Lovatt D, Xu Q, Liu W, Takano T, Smith NA, Schnermann J, Tieu K, Nedergaard M. Neuronal adenosine release, and not astrocytic ATP release, mediates feedback inhibition of excitatory activity. Proc Natl Acad Sci U S A. 2012; 109: 6265-70. doi: 10.1073/pnas.1120997109.

33. Van Gompel JJ, Bower MR, Worrell GA, Stead M, Chang SY, Goerss SJ, Kim I, Bennet KE, Meyer FB, Marsh WR, Blaha CD, Lee KH. Increased cortical extracellular adenosine correlates with seizure termination. Epilepsia. 2014; 55: 233-44. doi: 10.1111/epi.12511.

34. Li M, Kang R, Shi J, Liu G, Zhang J. Anticonvulsant activity of B2, an adenosine analog, on chemical convulsant-induced seizures. PLoS One. 2013; 8: e67060. doi: 10.1371/journal.pone.0067060.

35. Moezi L, Akbarian R, Niknahad H, Shafaroodi $\mathrm{H}$. The interaction of adenosine and morphine on pentylenetetrazole-induced seizure threshold in mice. Neuropharmacology. 2013; 72: 1-8. doi: 10.1016/j. neuropharm.2013.04.017.

36. Muzzi M, Coppi E, Pugliese AM, Chiarugi A. Anticonvulsant effect of AMP by direct activation of adenosine A1 receptor. Exp Neurol. 2013; 250: 189-93. doi: 10.1016/j.expneurol.2013.09.010.

37. Tosh DK, Paoletta S, Deflorian F, Phan K, Moss SM, Gao ZG, Jiang X, Jacobson KA. Structural sweet spot for A1 adenosine receptor activation by truncated (N)methanocarba nucleosides: receptor docking and potent anticonvulsant activity. J Med Chem. 2012; 55: 8075-90. doi: 10.1021/jm300965a.

38. Fukuda M, Suzuki Y, Hino H, Kuzume K, Morimoto T, Ishii E. Adenosine A1 receptor blockage mediates theophylline-associated seizures. Epilepsia. 2010; 51: 4837. doi: 10.1111/j.1528-1167.2009.02382.x.

39. Kochanek PM, Vagni VA, Janesko KL, Washington CB, Crumrine PK, Garman RH, Jenkins LW, Clark RS, Homanics GE, Dixon CE, Schnermann J, Jackson EK. Adenosine A1 receptor knockout mice develop lethal status epilepticus after experimental traumatic brain injury. J Cereb Blood Flow Metab. 2006; 26: 565-75. doi: 10.1038/ sj.jcbfm.9600218.

40. Huber A, Padrun V, Deglon N, Aebischer P, Mohler H, Boison D. Grafts of adenosine-releasing cells suppress seizures in kindling epilepsy. Proc Natl Acad Sci U S A. 2001; 98: 7611-6. doi: 10.1073/pnas.131102898.

41. Zhang D, Xiong W, Albensi BC, Parkinson FE. Expression of human equilibrative nucleoside transporter 1 in mouse neurons regulates adenosine levels in physiological and hypoxic-ischemic conditions. J Neurochem. 2011; 118: 4-11. doi: 10.1111/j.1471-4159.2011.07242.x.

42. Xu Z, Xu P, Chen Y, Liu J, Zhang Y, Lv Y, Luo J, Fang M, Zhang J, Wang J, Wang K, Wang X, Chen G. ENT1 inhibition attenuates epileptic seizure severity via regulation of glutamatergic neurotransmission. Neuromolecular Med. 2015; 17: 1-11. doi: 10.1007/s12017-014-8338-2.

43. Racine RJ. Modification of seizure activity by electrical stimulation. II. Motor seizure. Electroencephalogr Clin Neurophysiol. 1972; 32: 281-94. doi: 
44. Zhang Y, Li Z, Gu J, Zhang Y, Wang W, Shen H, Chen G, Wang X. Plic-1, a new target in repressing epileptic seizure by regulation of GABAAR function in patients and a rat model of epilepsy. Clin Sci (Lond). 2015; 129: 1207-23. doi: 10.1042/cs20150202.
45. Fang M, Lu Y, Chen GJ, Shen L, Pan YM, Wang XF. Increased expression of sonic hedgehog in temporal lobe epileptic foci in humans and experimental rats. Neuroscience. 2011; 182: 62-70. doi: 10.1016/j. neuroscience.2011.02.060. 